quoi il faut ajouter, pour le livre VI, L'histoire du tumulte d'Amboyse (attribuée à Hotman), Jean du Tillet, Nicole Gilles et quelques autres.

Si La Popelinière, comme la plupart des historiens de son temps, propose une vision tranchée de la politique (d'une part les Bourbons, protestants, d'autre part les Guises, catholiques), il reconnaît aux Guises des vertus et, comme l'indique la note 862 (483), il supprime les lignes peu amènes écrites par La Planche tout à sa haine des Guises, haine qui le poursuivit une grande partie de sa vie. À l'occasion de la dégradation d'Anne du Bourg par l'évêque de Paris, La Popelinière se contente de faire dire à Du Bourg « qu'il ne tenoit plus le caractere ny aucune marque du plus grand ennemy qu'il eust en ce monde » (110), là où La Place lui prête ces mots : " par ce moyen le caractere [c'est-à-dire la marque] de la beste, dont il est parlé en l'Apocalypse, luy estoit osté, et ne tenoit plus aucune tache de l'Antechriste de Rome » (110 : cité en note).

On regrettera que des passages des sources ne soient pas donnés en note de manière plus abondante. D'autre part, un glossaire eût été utile pour ce volume et aurait évité d'aller chercher ailleurs le sens de certains mots. Il manque également un index des noms cités dans les notes.

Un point de détail à propos de "Rosou » (74) : il faut sans doute lire "Roscu ", nom plus proche de celui de "Roscoff " (on ne prononçait pas les deux $f$ ), dont les habitants, du reste, s'appelaient jusqu'au XVIII siècle les « Roscouins".

FRANÇOIS ROUDAUT

Université Paul Valéry (Montpellier III)

Matula, Jozef, and Paul Richard Blum, eds.

Georgios Gemistos Plethon: The Byzantine and the Latin Renaissance.

Olomouc, CZ: Centre for Renaissance Texts / Univerzita Palackého v Olomouci, 2014. Pp. 462. ISBN 978-80-244-4423-9 (paperback) n.p.

This volume contains contributions from the international conference on Georgios Plethon (1355-1452) held in Olomouc, the Czech Republic, in May 2013. Although it is not explicitly stated, most of the articles seem to have been considerably lengthened. One, a defence of the divinity of Christ by Charitonymus Christonymus, written by John Demetracopoulos from 
the University of Patras, at almost one hundred pages long is by far the best-clearly argued and exhaustively commented-of all the contributions. Demetracopoulos's thesis is that this work was a reaction to the repudiation of Christ and the apostles in the introductory chapter of Plethon's Laws-a work that was burnt by Plethon's implacable enemy, Georgios Scholarios, also known as Gennadius, save for an abridgment of the opening chapters, which he preserved to show why he chose to destroy it. Demetracopoulos argues against the anti-Muslim character of the writing, supported by the use of Scripture, holding that Christonymos's defence was based on rational argument and was directed against Plethon, not Muslims. The chapter is replete with Greek quotations from Eusebius's Ecclesiastical History, Origen's Contra Celsum, John Chrysostom's proofs of Christ's divinity, and Scholarios's condemnations, all of which are not translated and therefore would pose a problem for the Greek-less reader.

The first article, by William Richard Blum, written in German, recounts the life of the infamous condottiere, Sigismondo Pandolfo Malatesta, and his admiration of Plethon as a champion of Neoplatonism. It should be remembered, however, that (as James Hankins has pointed out on several occasions) while the majority of scholars accept the charges of neo-paganism made against Plethon, beginning with Scholarios, many scholars are hesitant to accept this accusation. Towards the end of his life, during a military campaign against the Turks in the Peloponnesus, Malatesta besieged the town of Mistra, where Plethon had died, and rescued his body, bringing it back to Rimini where he had it buried in one of the arches on the exterior of the Tempio Malatestiano, designed by Leon Battista Alberti, which Blum considers Malatesta's bastion of neo-paganism.

An article on Plethon's theory of fate, which László Bene of the University of Budapest interprets as a reconstitution of Platonism with an anti-Christian bias, is followed by an essay entitled "Plethon's Philosophy of the Concept" by George Arabatzis of the University of Athens, which I found quite incomprehensible. There is no visible sequence of thought and the language is bewildering. In analyzing Plethon's Treatise on Virtues, he lists some virtuevalues, as he calls them, which he explains with the following scheme A->; $(\mathrm{BB}+\mathrm{AA}+\mathrm{B})$, and it goes on in this manner. But I will spare the reader and proceed to the next chapter, by Sergei Mariev of the University of Munich, which discusses Plethon's best known work: on the differences between Plato 
and Aristotle. It is a carefully argued philosophical disputation about the role of deliberation ( $\beta$ ou $\lambda \dot{\eta})$ in art and nature. Plethon argued with Aristotle in this case that deliberation is a constituent element of art and, a fortiori, of nature. His enemy Scholarios interpreted the word to mean doubt and hesitation, which Plethon refuted in a reply.

The discussion now turns from the Byzantine context to the Latin Renaissance. Mikhail Khorkov, of the Russian Academy of Sciences in Moscow, elucidates the difference between Plethon's concept of the soul in Plato's Phaedrus and the marginal comments of Nicholas of Cusa in a manuscript of Leonardo Bruni's Latin translation of the Phaedrus preserved in a manuscript in the Hospitalbibliothek in Bernkastel-Kues. A chapter by Vojtech Hladky of the Charles University in Prague discusses possible points of contact between these two men, speculating that they must have met on board ship from Constantinople to Venice and thence to Florence for the Council of Ferrara-Florence, in 1438-39. A further article, by Jozef Matula of Palacky University in Olomouc, Czech Republic, concerns Plethon's criticism of Averroes's interpretation of the Aristotelean conception of the immortality of the soul, although it is not certain from what sources Plethon derived his knowledge of Averroes, perhaps from Jewish communities in Constantinople. In another article, Davide Amendola of the Scuola Normale Superiore di Pisa compares fragments of Plethon's Opuscula de historia Graeca with Bruni's Commentarium rerum Graecarum, suggesting that the two men, in this case too, must have met at the Council of Ferrara-Florence. Walter Seitter of Vienna describes his discovery of a plausible portrait of Plethon in a very exoticallyclothed old man just to the right of Benozzo Gozzoli himself in his famous cycle of frescoes depicting the procession of the Magi in the chapel of the Palazzo Medici Riccardi in Florence. Seitter also sees an effigy of the old philosopher in Piero della Francesca's depiction of San Sigismondo in the fresco in the Tempio Malatestiano in Rimini.

Brigitte Tambrun-Krasker, of the Centre Nationale de la Recherche Scientifique in Paris, writes a very interesting account of the commentaries of the eleventh-century Byzantine philosopher Michael Psellos, and of Plethon on the so-called Chaldean Oracles of Zoroaster, which caused great controversy in seventeenth-century disputes about the Trinity. Blum contributes a second essay on the connections between Plethon and the Philhellenism of the nineteenth century. Niketa Siiossoglou, a professor in Athens, extrapolates modern ideas 
of nationalism from Plethon's use of certain political terms in his Laws. The last essay, by Jacek Raszewski of the University of Warsaw, examines the use of the heretic philosopher as a fictional figure in modern Greek literature, particularly in two Greek novels of the Generation of 1880: Alexandros Papdiamandis's Gypsy Girl and Kostis Palamas's Dodecalogue of a Gypsy.

Because of the abstruse and esoteric quality of the subject matter and the uncertain English of the authors, this collection does not make for easy reading, but it is a useful introduction to "the last Hellene."

CHARLES FANTAZZI

East Carolina University

\section{McSheffrey, Shannon.}

Seeking Sanctuary: Crime, Mercy, and Politics in English Courts, 1400-1550. Oxford: Oxford University Press, 2017. Pp. viii, 219. ISBN 978-0-1987-9814-9 (hardcover) US $\$ 80$.

Shannon McSheffrey's Seeking Sanctuary strives to fill a void that has remained a persistent feature of scholarship on the practice of sanctuary-seeking in England: the need for a single-volume study spanning the formative years of sanctuary's development and decline within the late-medieval and early-Tudor period. Indeed, despite an increasing awareness among historians of the fifteenth and early-sixteenth centuries that the practice of sanctuary provides a valuable insight into some of the most prevalent legal, cultural, and religious issues of the period, the impetus and events throughout the years covered by McSheffrey's study that shaped sanctuary's peculiar "English" character have, until now, been denied a comprehensive revision. In particular, this work demonstrates sanctuary's flexibility as part of - rather than antithetical to-the legal machinery in which it operated. Indeed, the notion that sanctuary remained a medieval anachronism until the "modernizing" Tudors served the coup de grâce in the mid-sixteenth century, McSheffrey argues, stubbornly endures.

McSheffrey commences her study at the turn of the fifteenth century, when the nature of seeking sanctuary in England underwent a significant change. In a number of the great religious houses throughout the realm, the medieval law of asylum that permitted an individual accused or guilty of felony to take 